\title{
Removal of Ethanolamine (ETA) and COD Produced in a Power Plant Wastewater by Nano-ZVI (Zerovalent Iron) and Hydrogen Peroxide $\left(\mathrm{H}_{2} \mathrm{O}_{2}\right)$
}

\author{
Jun Hee Lee, So Yeon Park, and Byoung Ho Lee
}

\begin{abstract}
Ethanolamine $\left(\mathrm{C}_{2} \mathrm{H}_{7} \mathrm{NO}\right.$, ETA $)$ is used in a power plant to prevent plumbing system from corrosion by maintaining $\mathrm{pH}$ at a certain level. Water flowing inside the plumbing system should periodically be cleaned using ion exchange resin. On the way of regeneration of the resin by sulfuric acid, ethanolamine wastewater is produced.

Removal mechanism of ETA has not been well established because it is very much resistant material in biodegradability, and even in chemical degradation. In this research high concentration of ETA ranging $5,000 \sim 9,000 \mathrm{mg} / \mathrm{l}$ was successfully removed closely down to zero level using nano sized zerovalent iron powder (nZVI) and appropriate amount of hydrogen peroxide $\left(\mathrm{H}_{2} \mathrm{O}_{2}\right)$. Organic material of high COD concentration $(6,000 \sim 13,500 \mathrm{mg} / \mathrm{l})$ was also contained in the wastewater along with high concentration of ETA. COD of the wastewater was simultaneously reduced down to 2,500 $6,000 \mathrm{mg} / \mathrm{l}$ along with ETA when catalytic oxidation of $\mathrm{nZVI}$ with hydrogen peroxide takes place, which can be removed further in a biological system of the following process. Removal rate of ETA showed highest at pH 3.

Wastewater produced in a power plant containing high concentrations of ETA and COD could be successfully treated up to the level, from which biological process can be applied for direct discharge to the natural water body.
\end{abstract}

Index Terms-Ethanolamine (ETA), hydrogen peroxide $\left(\mathrm{H}_{2} \mathrm{O}_{2}\right)$, nZVI (nano Zerovalent iron), nuclear power plant, COD.

\section{INTRODUCTION}

$\mathrm{pH}$ is normally controlled to prevent the water flow line from corrosion in industries where water is used in the circulating system[1]-[3]. To maintain $\mathrm{pH}$ at a certain level where chemical potential against corrosion is minimized, various materials have been used such as $\mathrm{NH}_{3}, \mathrm{C}_{2} \mathrm{H}_{7} \mathrm{NO}$ (ETA), and $\mathrm{C}_{4} \mathrm{H}_{9} \mathrm{NO}$ [4]. $\mathrm{NH}_{3}$ has been widely used for $\mathrm{pH}$ control in water pipe lines due to its easier availability. However ETA substituted $\mathrm{NH}_{3}$ as a $\mathrm{pH}$ control agent because $\mathrm{NH}_{3}$ is highly volatile at higher $\mathrm{pH}$ range, thereafter ETA has been used since 2001 in many power plants in Korea[4], [5]. However ETA is known to be highly refractory material in biodegradability and even in chemical oxidation processes [5]. Physicochemical properties of ETA are presented in Table I.

Manuscript received May 22, 2018; revised December 8, 2018.

Jun Hee Lee was with Michigan Technology Co., Ltd, Korea (e-mail: junh170@gmail.com).

So Yeon Park is with the Michigan Technology Co., Ltd, Korea (e-mail: soyeonpark5555@gmail.com).

Byoung Ho Lee is with the University of Ulsan, Korea (e-mail: bhlee@ulsan.ac.kr).
ETA is very stable material at high temperature such that a boiling point is $170.8^{\circ} \mathrm{C}$ as shown in Table I. pKa is also formed at high $\mathrm{pH} 9.496$. These two characteristics with the other ones in Table I let ETA be a good $\mathrm{pH}$ control agent in the pipe line where hot water or steam flows [6]. The hot water flowing pipe line in a closed system of a power plant is to be cleaned periodically using ion exchange resin [7], which produces ETA wastewater on the way of regeneration of ion exchange resin.

Wastewater produced from a power plant contains high concentrations of ETA $(6,000 \sim 9,000 \mathrm{mg} / \mathrm{l})$ and COD $(6,000$ - 13,500 mg/L) [8]. Many investigators have tried various technologies to remove ETA [8]-[11] including biodegradation and AOPs.

\begin{tabular}{c|c}
\multicolumn{2}{c}{ TABLE I: PHYSICOCHEMICAL PROPERTIES OF ETA [9] } \\
\hline Molecular weight $(\mathrm{g})$ & 61.08 \\
\hline Density & $1.0180\left(20^{\circ} \mathrm{C}\right)$ \\
\hline Melting/Boiling point $\left({ }^{\circ} \mathrm{C}\right)$ & $10.5 / 170.8$ \\
\hline Surface tension $(\mathrm{mN} / \mathrm{m})$ & $48.3175\left(20^{\circ} \mathrm{C}\right)$ \\
\hline Viscosity $\left(\mathrm{mN} . \mathrm{S} / \mathrm{m}^{2}\right)$ & $21.1\left(25^{\circ} \mathrm{C}\right)$ \\
\hline Dielectric constant & $31.94\left(20^{\circ} \mathrm{C}\right)$ \\
\hline $\begin{array}{c}\text { Dipole moment }(3.3356 \mathrm{x} \\
\left.10^{-3} \mathrm{C} . \mathrm{m}\right)\end{array}$ & 2.27 \\
\hline $\begin{array}{c}\text { Conductivity }\left(10^{-4}\right. \\
\mathrm{m}^{2} . \mathrm{S} / \mathrm{mole}^{-4}\end{array}$ & 47.2 \\
\hline Diffusivity $\left(10^{-5} \mathrm{~cm}^{2} / \mathrm{s}\right)$ & 1.124 \\
\hline Relative Volatility $\left(25^{\circ} \mathrm{C}\right)$ & $10^{-2.1}$ \\
\hline $\mathrm{pKa}\left(25^{\circ} \mathrm{C}\right)$ & 9.496
\end{tabular}

Hyun, Rhee, Kwon, Kim, and Cha found that mono ETA could be removed by activated sludge [9]. They could remove $1,000 \mathrm{mg} / \mathrm{l}$ of ETA in 5days, and $2,000 \mathrm{mg} / \mathrm{l}$ in 9days [9]. Fredriksen, and Jens tried to figure out the oxidative products of ETA [11]. Vevelstad, Grimstvedt, Elnan, Silva, and Svendsen investigated the effects of oxygen and temperature on ETA degradation. With increasing oxygen concentration and temperature, degradation rate of ETA was increased [12]. In their findings, $\mathrm{NH}_{3}, \mathrm{NO}^{2-}$, and $\mathrm{NO}^{3-}$ are among the final oxidative products of ETA [11], [12], which should be further removed in the following biological treatment. Fractions of nitrogen produced from ETA could be up to $78 \%$ [9].

Even with results of invaluable investigations by many researchers, their works have some limitations to be applied in a real wastewater treatment plant because their works have been performed in Lab scale, and for a pure ETA solution. Wastewater produced in a power plant contains very high concentrations of ETA unlike the ones which above mentioned researchers used, and other complex materials such as high concentration of COD material, and other toxic 
material of hydrazine $\left(\mathrm{N}_{2} \mathrm{H}_{4}\right)$. Hydrazine is used to remove oxygen in water, which suppresses corrosion in water flowing pipe line. Hydrazine is toxic to human and environment, as well as nitrification microorganisms [13]. $\mathrm{OH}^{*}$ radical has been used to remove chemical toxic pollutants [14], [15]. Sun suggested that application of nZVI was a good technology in decolorization of cationic dye methylene blue [14]. Bremner investigated the degradation of the model pollutant phenol with hydroxyl radicals generated from zerovalent iron and hydrogen peroxide [15]. $\mathrm{OH}^{*}$ radical is assumed to be generated by the following $(1) \sim(3)$ processes [8].

$$
\begin{gathered}
\mathrm{Fe}^{0}+\mathrm{O}_{2}+2 \mathrm{H}^{+} \rightarrow \mathrm{Fe}^{2+}+\mathrm{H}_{2} \mathrm{O}_{2} \\
\mathrm{Fe}^{0}+\mathrm{H}_{2} \mathrm{O}_{2} \rightarrow \mathrm{Fe}^{2+}+2 \mathrm{OH}^{-} \\
\mathrm{Fe}^{0}+\mathrm{H}_{2} \mathrm{O}_{2} \rightarrow \mathrm{Fe}^{3+}+\mathrm{OH}^{*}+\mathrm{OH}^{-}
\end{gathered}
$$

Due to highly refractory, toxic, and complexity of power plant wastewater, treatment processes of ETA have not been clearly established yet even though ETA is not allowed to discharge into natural water body at all by law [5], [6].

In this paper, removal mechanisms of ETA contained in power plant wastewater have been suggested using nZVI and $\mathrm{H}_{2} \mathrm{O}_{2}$. Oxidation potential of highly reactive $\mathrm{OH}^{*}$ radical is used in removing ETA, COD, and other material such as hydrazine.

\section{EXPERIMENTAL METHODS}

\section{A. ETA Wastewater Sample}

Wastewater produced in a nuclear power plant in Korea was collected under strict surveillance of the authority. Taken sample was stored in polyethylene vessel. Concentrations of ETA, and COD of the wastewater sample were measured according to standard methods. COD was estimated by the standard dichromate method ASTM D1252 (ASTM D1252-06(2012)). ETA was analyzed using ion chromatography (DIONEX ICS-5000 DP) equipped with CG-12A (guard column) and CS-12A (analytical column).

\section{B. nZVI (Nano Size Zerovalent Iron)}

nZVI having $99.8 \%$ purity were purchased from DittoTechnology Co., Ltd. They exhibited an average particle size of $70 \mathrm{~nm}$. nZVI sample was stored not to be exposed to atmospheric air. And bottle of nZVI was open, and appropriate amounts of samples were taken just before it was used.

\section{Raw Water Characteristics}

Raw water characteristics were varied with some range, which is shown in Table II.

TABLE II: RAW WASTEWATER CHARACTERISTICS

\begin{tabular}{c|c|c}
\multicolumn{2}{c|}{ TABLE II: RAW WASTEWATER CHARACTERISTICS } \\
\hline & Unit & Concentrations \\
\hline ETA & $\mathrm{mg} / \mathrm{l}$ & $5,000 \sim 9,000$ \\
\hline COD & $\mathrm{mg} / \mathrm{l}$ & $6,000 \sim 13,500$ \\
\hline T-N (Total & $\mathrm{mg} / \mathrm{l}$ & $2,000 \sim 3,500$ \\
Nitrogen) & & \\
\hline
\end{tabular}

$\mathrm{pH}$ range of the wastewater was $0 \sim 1.5$.
After screening test, experiments have been performed at $\mathrm{pH} 3$, which is turned out to be the optimum $\mathrm{pH}$ for removing ETA in wastewater. Experimental setup is shown in Fig. 1. (a) represents raw wastewater, (b) is after $\mathrm{pH}$ adjustment to 3, (c) is after $\mathrm{nZVI}$ addition, and (d) is shown after $\mathrm{H}_{2} \mathrm{O}_{2}$ addition. Salinity of wastewater was about $4 \sim 6 \%$.

After $\mathrm{pH}$ adjustment to $3, \mathrm{CaSO}_{4}$ (gypsum) was settled on the bottom of the vessel as it may be seen in (b) of Fig. 1. As soon as nZVI is added in the wastewater, vigorous oxidation reaction of nZVI took place like (c). After addition of $\mathrm{H}_{2} \mathrm{O}_{2}$ in the nZVI added sample, even more vigorous reaction took place like (d). The reactor vessel was placed for 24 hours for sufficient reaction period.

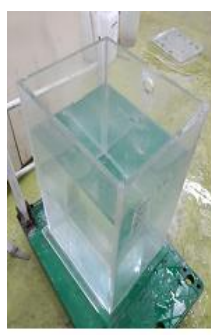

(a)

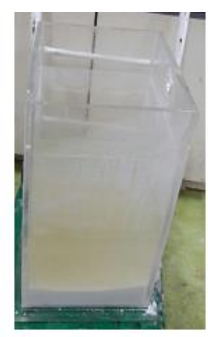

(b)

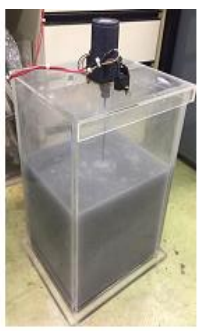

(c)
Fig. 1 Experimental set up.

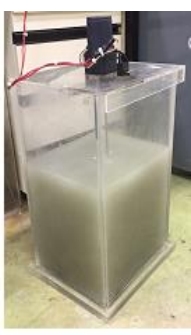

(d)

\section{RESUlTS AN DisCUSSION}

Due to relatively easier measurement, COD was used as an index parameter in the study. After finding the optimum condition of a catalytic oxidation of nZVI and $\mathrm{H}_{2} \mathrm{O}_{2}$ in removing COD, ETA was measured at the final stage assuming that ETA is removed highest at the same optimum condition.

\section{A. Screening Test for Finding an Optimum $\mathrm{pH}$}

Experiments have been performed in various $\mathrm{pHs}$ to figure out the optimum $\mathrm{pH}$ for the catalytic oxidation of nZVI and $\mathrm{H}_{2} \mathrm{O}_{2}$. And the optimum $\mathrm{pH}$ was decided at which COD removal was highest. Lee et al. reported the optimal $\mathrm{pH}$ in catalytic oxidation of nZVI and $\mathrm{H}_{2} \mathrm{O}_{2}$ was 3 for maximum COD removal [8]. In screening test, Fig. 2 shows that the lowest $\mathrm{COD}$ concentration was obtained at $\mathrm{pH} 3$ after treated by $\mathrm{nZVI}$ and $\mathrm{H}_{2} \mathrm{O}_{2}$ oxidation, so that it was decided that the optimum $\mathrm{pH}$ was 3 . Otherwise specified experiments have been done at $\mathrm{pH} 3$ in the study. Original $\mathrm{pH}$ of wastewater was close to zero. COD concentration of power plant wastewater was $9,500 \mathrm{mg} / \mathrm{l}$.

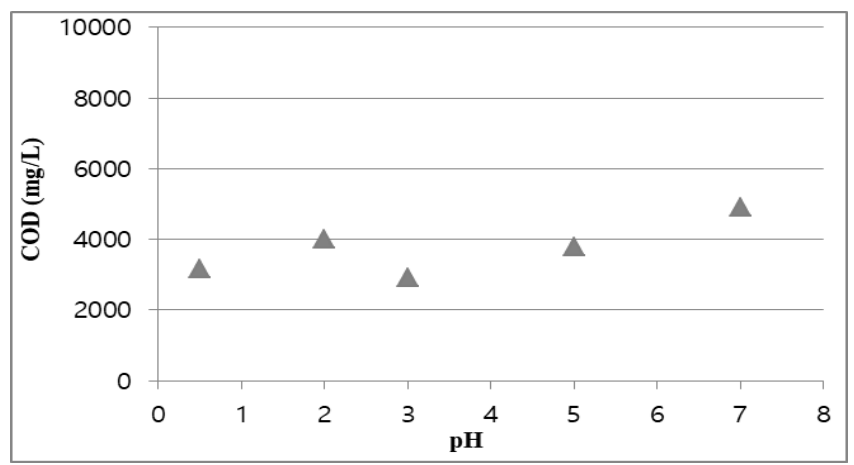

Fig. 2. Screening test for finding optimum $\mathrm{pH}$ on COD removal (nZVI $\left.(10 \mathrm{mg} / \mathrm{L})+\mathrm{H}_{2} \mathrm{O}_{2}(50 \mathrm{ml} / \mathrm{L})\right)$. 


\section{B. Effect of Hydrogen Peroxide $\left(\mathrm{H}_{2} \mathrm{O}_{2}\right)$ Concentration}

Effect of $\mathrm{H}_{2} \mathrm{O}_{2}$ concentration was investigated in the oxidation. COD removal was increased with $\mathrm{H}_{2} \mathrm{O}_{2}$ concentration up to about $150 \mathrm{ml} / \mathrm{L}$ as shown in Fig. 3. $35 \%$ of $\mathrm{H}_{2} \mathrm{O}_{2}$ was used in the test. $\mathrm{H}_{2} \mathrm{O}_{2}$ used in the experiment was manufactured in Taegwang co. LTD, Korea. COD was removed down to $2,800 \mathrm{mg} / \mathrm{l}$ from $9,500 \mathrm{mg} / \mathrm{l}$ by $\mathrm{nZVI} 1 \mathrm{~g} / \mathrm{L}$, and $150 \mathrm{ml} / \mathrm{L}$ of $\mathrm{H}_{2} \mathrm{O}_{2}$ for about 24 hours. At the same condition, COD was removed to $3,400 \mathrm{mg} / 1$ by $50 \mathrm{ml} / \mathrm{L}$ of $\mathrm{H}_{2} \mathrm{O}_{2}$. Both concentrations of COD may be removed by the following biological treatment process up to the dischargeable level to a natural water body. $50 \mathrm{ml} / \mathrm{L}$ of $\mathrm{H}_{2} \mathrm{O}_{2}$ may be an optimum dose in economic point of view.

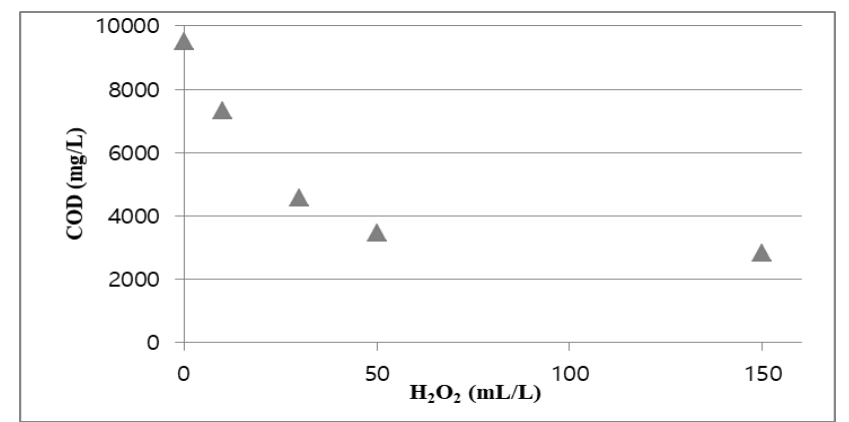

Fig. 3. Effect of $\mathrm{H}_{2} \mathrm{O}_{2}$ concentration on ETA degradation (nZVI 1g/L, $\mathrm{pH}$ ).

\section{Effect of Nano Zerovalent Iron (nZVI) Dose}

Effect of nZVI concentration on COD removal by the oxidation with $\mathrm{H}_{2} \mathrm{O}_{2}$ was investigated. As shown in Fig. 4, nZVI concentration was not sensitive as much as $\mathrm{H}_{2} \mathrm{O}_{2}$ does. It is believed that nZVI acts as catalyst in the oxidation reaction [15], so that if concentration of $\mathrm{nZVI}$ is over in some level, nZVI effect on COD removal was not increased very much with increasing its concentration. Optimum dose of nZVI was revealed to be $1 \mathrm{~g} / \mathrm{L}$ in the experiment like in Fig. 4. From the experiment result, nano ZVI was used $1 \mathrm{~g} / \mathrm{L}$ throughout the remaining experiment.

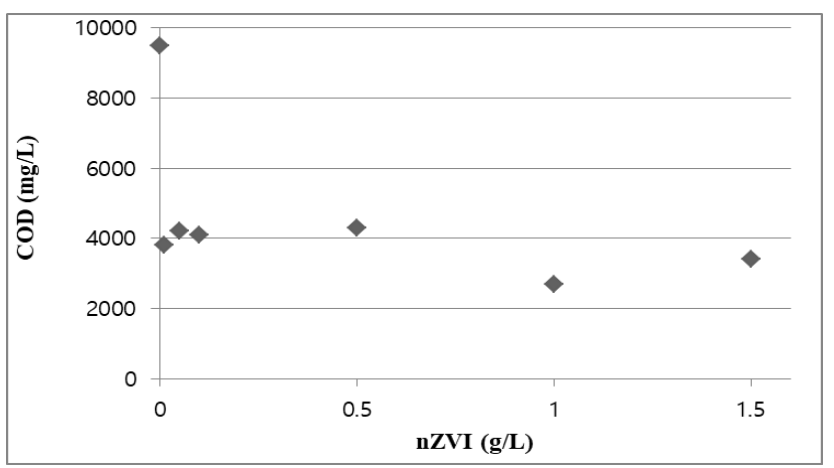

Fig. 4. Effect of nano zerovalent iron (nZVI) concentration $\left(\mathrm{H}_{2} \mathrm{O}_{2} 50 \mathrm{ml} / \mathrm{L}\right.$, $\mathrm{pH} 3)$.

\section{Effect of Reaction Time}

Oxidation reaction of nZVI and $\mathrm{H}_{2} \mathrm{O}_{2}$ has completed in about 10 hours as shown in Fig. 5. Economic reaction time may be about 5hours. In 5 hours, most of COD contained in wastewater was reduced to its minimum level.

\section{E. ETA Removal}

About 7,500mg/l of ETA was removed $99 \%$ to $51 \mathrm{mg} / \mathrm{L}$ by catalytic oxidation of nZVI with $\mathrm{H}_{2} \mathrm{O}_{2}$. ETA was effectively removed if nZVI was used with $\mathrm{H}_{2} \mathrm{O}_{2}$ as it can be seen in Table III. Even if ETA was known to be very much refractory material in power plant wastewater [8], it was proved that nZVI catalytic oxidation with $\mathrm{H}_{2} \mathrm{O}_{2}$ could be a solution for direct discharge of the treated water to the natural water body after following biological processes.

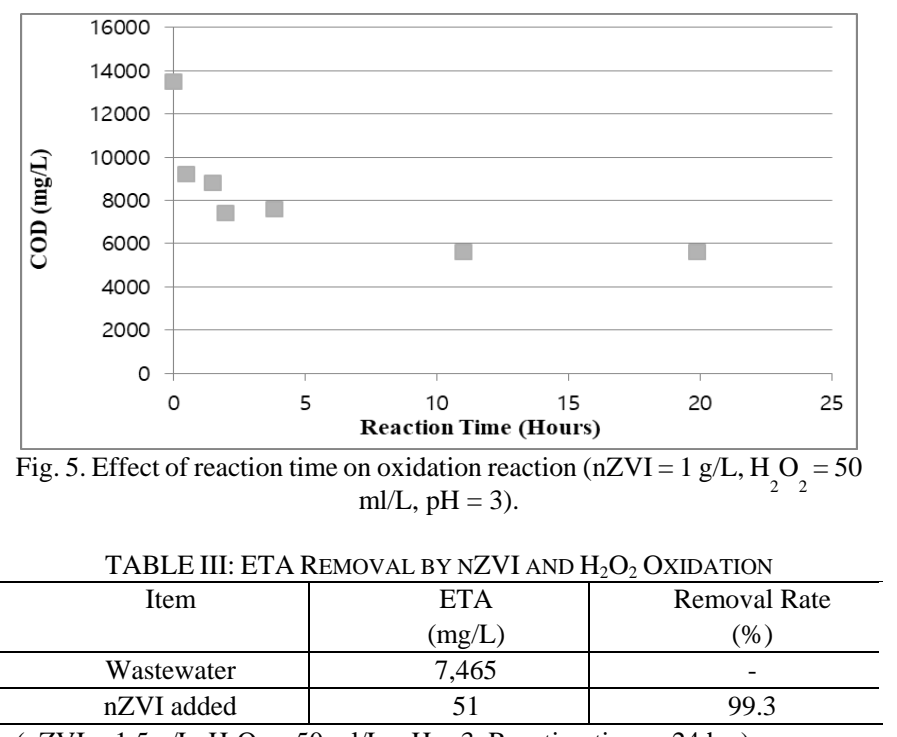

$\left(\mathrm{nZVI}=1.5 \mathrm{~g} / \mathrm{L}, \mathrm{H}_{2} \mathrm{O}_{2}=50 \mathrm{ml} / \mathrm{L}, \mathrm{pH}=3\right.$, Reaction time $\left.=24 \mathrm{hrs}\right)$

\section{CONCLUSION}

Wastewater containing high concentrations of ETA and COD is produced in power plant. ETA is regulated not to be discharged to the natural water body at all. Due to its highly refractory characteristics, mechanisms to treat ETA have not been clearly figured out. In this paper, wastewater containing ETA taken from a nuclear power plant was treated using nZVI and $\mathrm{H}_{2} \mathrm{O}_{2} .9,800 \mathrm{mg} / \mathrm{l}$ of ETA was removed down to about below $290 \mathrm{mg} / \mathrm{l}$ by the catalytic oxidation of nZVI (1g/L) with $\mathrm{H}_{2} \mathrm{O}_{2}(150 \mathrm{ml} / \mathrm{L})$. COD was also removed from $13,500 \mathrm{mg} / \mathrm{l}$ to $6,100 \mathrm{mg} / \mathrm{l}$ by the same oxidation reaction. It was found that ETA wastewater produced in power plants could be treated successfully by nZVI catalytic oxidation with $\mathrm{H}_{2} \mathrm{O}_{2}$.

\section{ACKNOWLEDGEMENT}

This work was supported by the K-Cloud Research Project of the Korea Hydro \& Nuclear Power Co., LTD entitled "Removal of Ethanolamine (ETA) and COD Produced in a Power Plant Wastewater by nano-ZVI (Zerovalent Iron) and Hydrogen Peroxide (H2O2)".

\section{REFERENCES}

[1] F. Nordmann, "Aspects on chemistry in French nuclear power plants," J. Solution Chemistry, 2003, vol. 32, no. 10, 2004.

[2] F. Cattant, D. Crusset, and D. Feron, "Corrosion issues in nuclear industry today, materials today," vol. 11, no. 10, 2008, pp. 32-37.

[3] P. J. Millett and K. Fruzzetti, "In status of application of amines in US PWRs," in Proc. International Conference on the Interaction of Organics and Organic Cycle Treatment Chemicals in Water, Steam and Materials, Stuttgart, Germany, October 4-6, 2005.

[4] M. J. Hammer, "Water \& wastewater technology," 1986.

[5] S. J.-Y. Park, "Removal of COD and T-N caused by ETA from nuclear power plant wastewater using 3D packed bed Bipolar electrode system," J. Korean Soc. Water and Wastewater, vol. 26, 2012, pp. 409-421. 
[6] B\&W Nuclear Technologies, Toledo Edison Company, Qualification Testing of Three Advanced Amines for Secondary-System pH Control in Once-Through Steam Generator Plants, EPRI TR-103098, Project S520-5, Electric Power Research Institute (EPRI): Palo Alto, CA, 1994.

[7] B. Carlin and L. Brown, "Effect of amines on anion exchange resin kinetics," EPRI Secondary Chemistry Optimization Workshop, July, 1994.

[8] S. D. Lee, S. R. Mallampati, and B. H. Lee, "Enhanced removal of ethanolamine from secondary system of nuclear power plan wastewater by novel hybrid nano zero-valent iron and pressurized ozone initiated oxidation process," Environ Sci Pollut Res., June 2017.

[9] J.-T. Hyun, I. H. Rhee, S. H. Kwon, D. Kim, and D. Cha, "Bacterial degradation of Monoethanolamine," Korean J. Biotechnol. Bioeng, vol. 22, no. 3, 2007, pp. 157-161.

[10] S. J. Vevelstad et al., "Oxidative degradation of 2-ethanolamine: The effect of oxygen concentration and temperature on product formation," International Journal of Greenhouse Gas Control, vol. 18, 2013, pp. $88-100$.

[11] S. B. Fredriksen and K.-J. Jens, "Oxidative degradation of aqueous amine solutions of MEA, AMP, MDEA, Pz: A review," Energy Procedia, vol. 37, 2013, pp. 1770-1777

[12] S. J. Vevelstad, A. Grimstvedt et al., "Oxidative degradation of 2-ethanolamine: The effect of oxygen concentration and temperature on product formation," International Journal of Greenhouse Gas Control, vol. 18, 2013, pp. 88-100.

[13] S. Parodi et al., "DNA-damaging activity in vivo and bacterial mutagenicity of sixteen hydrazine derivatives as related quantitatively to their carcinogenicity," Cancer Research, vol. 41, issue 4, April 1981.
[14] X. Sun et al., "Removal of cationic dye methylene blue by zero-valent iron: Effects of $\mathrm{pH}$ and dissolved oxygen on removal mechanisms," Journal of Environmental Science and Health, vol. 50, 2015.

[15] D. H. B. Arthur et al., "Phenol degradation using hydroxyl radicals generated from zero-valent iron and hydrogen peroxide," Applied Catalysis B: Environmental, vol. 63, issues 1-2, 22 March 2006, pp. 15-19.

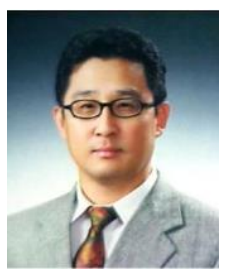

Byoung Ho Lee was born on May 10, 1953 in republic of Korea. He got the Ph.D in environmental health science at the University of Michigan, USA. 1990; the MS in environmental engineering at the University of Michigan, USA. 1986; the BS in civil engineering at Busan National University, Korea. 1981.

$\mathrm{He}$ is professor at the University of Ulsan. Korea. He got the Best Paper Award from Journal of AWWA in Engineering Division. 1993. "Locating Monitoring Stations in Water Distribution Network". His research interests are DAF, DOF, and AOP using nano Zerovalent Iron.

Jun Hee Lee was born on March 27, 1970 in republic of Korea, who got the $\mathrm{Ph} . \mathrm{D}$ in environmental engineering, University of Michigan, Ann Arbor, MI 48105. Jun Hee Lee is vice president, Michigan Technology Co., LTD. Technology Renovation BLD, Korea.

So Yeon Park was born on Feburary 26, 2016 in republic of Korea, who got the bachelor of engineering in ecological engineering at the Pukyung National University. 